\title{
Reaction of Carboxylic Dyes with Wool and Polyamide. Part III: Effect of the Activating Agent
}

\author{
M. S. T. Gonçalves, ${ }^{a}$ A. M. F. Oliveira-Campos, ${ }^{a *}$ J. C. V. P. \\ Moura, ${ }^{a}$ H. L. S. Maia, ${ }^{a}$ J. I. N. R. Gomes ${ }^{b} \&$ R. Hrdina ${ }^{c}$ \\ ${ }^{a}$ Departamento de Química, Universidade do Minho, 4700 Braga, Portugal \\ ${ }^{b}$ Departamento de Engenharia Têxtil, Universidade do Minho, 4800 Guimarães, Portugal \\ ${ }^{c}$ Idite Minho, Palácio de Vila-Flor, 4800 Guimarães, Portugal
}

(Received 22 January 1997; accepted 24 February 1997)

\begin{abstract}
Dyes containing a carboxylic acid group had been shown to react with wool and polyamide fibres when activated with ethyl chloroformate (Parts I and II). One of the dyes, 3-aminobenzoic acid $\rightarrow N, N$-dimethylaniline, was, in this work, activated with other chlorofirmates, so as to improve the dyeing conditions. Benzyl chloroformate was found to be a good substitute since it is not as volatile as ethyl chloroformate, which suggests that it will be easier to apply in practical dyeing conditions. The yield of the reaction with cyclohexylamine is similar to the one obtained with ethyl chloroformate, suggesting that the fixation of the dye on wool or polyamide will be much the same. The fastness results are also equivalent. (C) 1998 Elsevier Science Ltd
\end{abstract}

Keywords: carboxylic, reactive, dyes, wool, polyamide.

\section{INTRODUCTION}

Reactive dyes containing carboxylic acid groups were first developed by Burlington Industries Inc. in 1978 and they were applied successfully to cellulosic fibres [1]. In previous work we investigated the fixation of carboxylic acid dyes on polyamide and wool fibres and found [2] that the activation of

* Corresponding author.

Parts I and II refer to references 2 and 4, respectively. 
the $\mathrm{CO}_{2} \mathrm{H}$ group by ethyl chloroformate gave better fastness results due to the formation of the more reactive mixed anhydride group. The stability of the dyes was however poor and the activation had to be done immediately before the application to the fibres.

In a later work the dyes in the activated form were isolated and applied to wool and polyamide fibres in the same manner as the freshly activated dyes had been [3]. The stability of these dyes was found to be very good and a study on the hydrolysis showed the dependency of the dye on the $\mathrm{pH}$, and the rate of reaction at various $\mathrm{pH}$ values was measured [4]. The best $\mathrm{pH}$ range of reaction was found to be 6-7, the dyeings needing no further fixation treatment with ammonia to achieve good fixation and fastness results. These results were not however, as good as those obtained with freshly activated dye, and for that reason we resumed the research on the process of activation.

Since one of the problems of the process of application of the dye and its fixation was the product of activation itself, which is extremely reactive and volatile, in this work we tried to improve these conditions by testing other chloroformates of lower boiling point, while maintaining at the same time the yields and washfastness ratings. The yields were assessed in the reaction with model amines and the washfastness was evaluated on wool and polyamide fibres.

\section{RESULTS AND DISCUSSION}

To determine the optimum time for the activation to be considered completed, an HPLC study was carried out as described below.

The dye was activated as before and the activation was followed by HPLC (Table 1). An aliquot of the solution was diluted with acetonitrile to a fixed

TABLE 1

Experimental and Analytical Data for Mixed Anhydrides 2

\begin{tabular}{|c|c|c|c|c|c|}
\hline Compound & $\begin{array}{l}\text { Yield } \\
(\%)\end{array}$ & $\begin{array}{l}m . p . \\
\left({ }^{\circ} \mathrm{C}\right)\end{array}$ & $\begin{array}{c}v\left(\mathrm{~cm}^{-1}\right) \\
(\mathrm{KBr})\end{array}$ & $\begin{array}{c}\text { Mass spect. } \\
m / z(\%)\end{array}$ & $\begin{array}{l}\text { Retention time } \\
(H P L C) \text { (min) }\end{array}$ \\
\hline 2(a) & 8.5 & $192-196$ & $\begin{array}{l}1805 \\
1743\end{array}$ & & 1.47 \\
\hline $\mathbf{2 b}$ & 37 & $196-199$ & $\begin{array}{l}1790(s) \\
1724\end{array}$ & $\begin{array}{c}448\left(\mathrm{M}^{+}, 3 \%\right) \\
\text { CI (Isobutane) }\end{array}$ & 1.53 \\
\hline $2 c$ & - & Oil & $\begin{array}{l}1818, \\
1786(s) \\
1727\end{array}$ & & - \\
\hline
\end{tabular}


volume and then injected into the HPLC column (RT values in Table 1). The optimum activation times were $5 \mathrm{~min}$ for 2(a) and less than $1 \mathrm{~min}$ for 2(b). A signal could not be observed for the activated form of 2(c) but only for its ester 4(c).

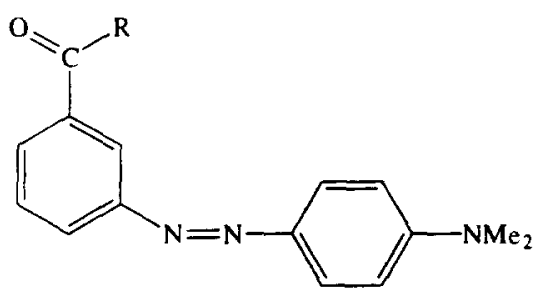
1) $\mathrm{R}=\mathrm{OH}$
2a) $\mathrm{R}=\mathrm{OCO}_{2} \mathrm{CH}_{2} \mathrm{Ph}$
2b) $\mathrm{R}=\mathrm{OCO}_{2} \mathrm{CH}_{2} \longrightarrow-\mathrm{NO}_{2}$
2c) $\mathrm{R}=\mathrm{OCO}_{2} \mathrm{CH}_{2} \mathrm{CCl}_{3}$
2d) $\mathrm{R}=\mathrm{OCO}_{2} \mathrm{Et}$
3) $\mathrm{R}=-\mathrm{H}-\mathrm{N}$
4a) $\mathrm{R}=\mathrm{OCH}_{2} \mathrm{Ph}$
4b) $\mathrm{R}=\mathrm{OCH}_{2}-\mathrm{NO}_{2}$
4c) $\mathrm{R}=\mathrm{OCH}_{2} \mathrm{CCl}_{3}$
4d) $\mathrm{R}=\mathrm{OEt}$

The activation of dye 1 was effected at low temperature with several chloroformates: benzyl, p-nitrophenyl and 2,2,2-trichloroethyl. The mixed anhydrides 2(a)-2(c) were isolated in low yields as solids (a), (b) or an oil (c) and showed the characteristic absorption bands for the carbonyl group at $1786-1790 \mathrm{~cm}^{-1}$ (Table 1). Previously we had also isolated and characterised the mixed anhydride 2(d) resulting from the same model dye and ethyl chloroformate [4].

When cyclohexylamine was added to the solutions of the mixed anhydrides the amide 3 and the corresponding esters 4 (Table 2) were obtained as byproducts and characterised. It was observed that a better yield for the amide 3 was obtained with $p$-nitrophenyl $(54 \%)$ and 2,2,2-trichloroethyl $(53 \%)$ chloroformates, the last one giving the highest yield for the ester $\mathbf{4}(\mathrm{c})$. These

TABLE 2

Experimental Data for Esters 4 as By-products on the Synthesis of Amide 3

\begin{tabular}{lcccc}
\hline Compound & $\begin{array}{c}\text { Yield } \\
(\%)\end{array}$ & $\begin{array}{c}\text { Activation time } \\
(\text { min })\end{array}$ & $\begin{array}{c}\text { Yield on 3* } \\
(\%)\end{array}$ & $\begin{array}{c}\text { Retention time } \\
(\text { HPLC })(\text { min })\end{array}$ \\
\hline 4(a) & 8 & 5 & $33(64)$ & 1.81 \\
4(b) & 13 & 1 & $54(79)$ & 1.77 \\
4(c) & 47 & 0.5 & $53(-)$ & 2.1 \\
4(d) & 17 & & $42(67)$ & \\
\hline
\end{tabular}

* Yields in brackets refer to the preparation in water solution, where no esters were obtained. 
TABLE 3

Analytical Data for Esters 4

\begin{tabular}{lcccc}
\hline Compound & $\begin{array}{c}m . p . \\
\left({ }^{\circ} \mathrm{C}\right)\end{array}$ & $\begin{array}{c}v\left(\mathrm{~cm}^{-1}\right) \\
(\mathrm{KBr})\end{array}$ & $\begin{array}{c}\text { Mass spect. m/z }(\%) \\
\text { CI }(\text { isobutane })\end{array}$ & $\begin{array}{c}\lambda_{\max }(\varepsilon) \\
(\mathrm{CHCl})\end{array}$ \\
\hline 4(a) & $119-120$ & 1718 & $360\left(\mathrm{M}^{+}+1,100 \%\right)$ & $417(8120)$ \\
4(b) & $135-139$ & 1724 & $405\left(\mathrm{M}^{+}+1,100 \%\right)$ & $422(22,500)$ \\
$\mathbf{4 ( c )}$ & $141-142$ & 1730 & - & $418(10,000)$ \\
\hline
\end{tabular}

TABLE 4

Analyses of HRMS of Esters 4

\begin{tabular}{lcc}
\hline Compound & Theory (\%) & Found (\%) \\
\hline 4(a) & $\mathrm{C}_{22} \mathrm{H}_{21} \mathrm{~N}_{3} \mathrm{O}_{2}, \mathrm{H}_{2} \mathrm{O}$ & $\mathrm{C}, 70.03 ; \mathrm{H}, 6.1 ; \mathrm{N}, 11.14$ \\
& $\mathrm{C}, 69.81 ; \mathrm{H}, 5.93 ; \mathrm{N}, 10.79$ & \\
4(b) & $\mathrm{C}_{22} \mathrm{H}_{20} \mathrm{~N}_{4} \mathrm{O}_{4}, 0.5 \mathrm{Et}_{2} \mathrm{O}$ & $\mathrm{C}, 64.98 ; \mathrm{H}, 5.40 ; \mathrm{N}, 12.96$ \\
& $\mathrm{C}, 65.31 ; \mathrm{H}, 5.67 ; \mathrm{N}_{12.70}$ & \\
4(c) & $\mathrm{C}_{17} \mathrm{H}_{16}{ }^{35} \mathrm{Cl}_{2}{ }^{37} \mathrm{ClN}_{3} \mathrm{O}_{2}$ & \\
& 401.027860 & 401.027746 \\
\hline
\end{tabular}

TABLE 5

NMR Data for Esters 4

\begin{tabular}{|c|c|}
\hline Compound & ${ }^{l} H N M R$ \\
\hline $4(b)$ & $\begin{array}{c}\delta\left(300 \mathrm{MHz}, \mathrm{CDCl}_{3}\right) 3.1(6 \mathrm{H}, \mathrm{s}, 2 \times \mathrm{Me}), 5.4\left(2 \mathrm{H}, \mathrm{s}, \mathrm{CH}_{2}\right), 6.74 \\
\left(2 \mathrm{H}, \mathrm{d} \mathrm{J} 8.6 \mathrm{~Hz} .2 \times \mathrm{Ar}-\mathrm{H} \text { ortho to } \mathrm{NMe}_{2}\right), 7.22-7.58(6 \mathrm{H}, \mathrm{m}, 5 \times \\
\left.\mathrm{Ar}-\mathrm{H} \text { and } 5-\mathrm{H}), 7.88(2 \mathrm{H}, \mathrm{d} \mathrm{J} 8.6 \mathrm{~Hz}, 2 \times \mathrm{Ar}-\mathrm{H} \text { meta to } \mathrm{NMe})_{2}\right), 8.0 \\
\text { and } 8.07(2 \mathrm{H}, 2 \times \mathrm{d} \mathrm{J} 7.9 \mathrm{~Hz}, 4-\mathrm{H} \text { and } 6-\mathrm{H}), 8.51(1 \mathrm{H}, \mathrm{s}, 2-\mathrm{H})\end{array}$ \\
\hline $4(c)$ & $\begin{array}{c}\delta\left(300 \mathrm{M}, \mathrm{CDCl}_{3}\right) 3.09(6 \mathrm{H}, \mathrm{s}, 2 \times \mathrm{Me}), 5.48\left(2 \mathrm{H}, \mathrm{s}, \mathrm{CH}_{2}\right), 6.74(2 \mathrm{H}, \mathrm{d} \mathrm{J} \\
\left.9 \mathrm{~Hz}, 2 \times \mathrm{Ar}-\mathrm{H} \text { ortho to } \mathrm{NMe}_{2}\right), 7.54(1 \mathrm{H}, \operatorname{tap} \mathrm{J} 7.6 \mathrm{~Hz}, 5-\mathrm{H}), 7.62 \\
\left(2 \mathrm{H}, \mathrm{d} \mathrm{J} 8.4 \mathrm{~Hz}, 2 \times \mathrm{Ar}-\mathrm{H} \text { meta to } \mathrm{NO}_{2}\right), 7.88(2 \mathrm{H}, \mathrm{d} \mathrm{J} 9 \mathrm{~Hz}, 2 \times \\
\left.\mathrm{Ar}-\mathrm{H} \text { meta to } \mathrm{NMe} \mathrm{N}_{2}\right), 8.0-8.09(2 \mathrm{H}, 3 \times \mathrm{m}, 4 \text { and } 6-\mathrm{H}), 8.25(2 \mathrm{H}, \\
\left.\text { d J } 8.4 \mathrm{~Hz}, 2 \times \mathrm{Ar}-\mathrm{H} \text { ortho ao } \mathrm{NO}_{2}\right), 8.5(1 \mathrm{H}, \operatorname{tap} \mathrm{J} 1,5 \mathrm{~Hz}, 2-\mathrm{H})\end{array}$ \\
\hline $4(d)$ & $\begin{array}{r}\delta\left(300 \mathrm{MHz}, \mathrm{CDCl}_{3}\right) 3.12\left(6 \mathrm{H}, \mathrm{s}, \mathrm{NMe}_{2}\right), 5.02\left(2 \mathrm{H}, \mathrm{s}, \mathrm{CH}_{2}\right) 6.76(2 \mathrm{H}, \\
\left.\text { d J 9.5 Hz, } 2 \times \mathrm{ArH} \text { ortho to } \mathrm{NMe}_{2}\right), 7.58(1 \mathrm{H}, \mathrm{t} \mathrm{J} 7.6 \mathrm{~Hz}, 5-\mathrm{H}), 7.85 \\
\left(2 \mathrm{H}, \mathrm{d} \mathrm{J} 9.5 \mathrm{~Hz}, 2 \times \mathrm{Ar}-\mathrm{H} \text { meta to } \mathrm{NMe}_{2}\right), 8.04-8.1 \text { and } 8.1-8.18(2 \mathrm{H}, \\
4 \times \mathrm{m}, 4 \text { and } 6-\mathrm{H}), 8.56(1 \mathrm{H}, \operatorname{tap} \mathrm{J} 1.5 \mathrm{~Hz}, 2-\mathrm{H})\end{array}$ \\
\hline
\end{tabular}

esters were characterised by spectroscopic methods and either elemental analysis or high resolution mass spectrometry (Tables 3, 4 and 5).

To approach the dyeing process of the fibres, the preparation of amide 3 was performed in water where no esters were isolated and better yields of the amide were obtained (Table 2). 
TABLE 6

Wash Fastness of Dyed Fibres

\begin{tabular}{|c|c|c|c|c|c|c|}
\hline \multirow{3}{*}{$\begin{array}{l}\text { Activating reagent } \\
\text { (chloroformate) }\end{array}$} & \multicolumn{2}{|c|}{ Change in shade } & \multicolumn{4}{|c|}{ Staining } \\
\hline & \multirow[t]{2}{*}{ Wool } & \multirow[t]{2}{*}{ Nylon- 6.6} & \multicolumn{2}{|c|}{ Wool } & \multicolumn{2}{|c|}{ Nylon-6.6 } \\
\hline & & & Cotton & Wool & Wool & Nylon-6.6 \\
\hline None & $1-2$ & 2 & 3 & 2 & 4 & $4-5$ \\
\hline Ethyl & $4-5$ & 5 & $4-5$ & $3-4$ & $4-5$ & 5 \\
\hline Benzyl & 4 & 5 & 4 & $3-4$ & $4-5$ & 4 \\
\hline 4-Nitrobenzyl & 4 & $4 / 5$ & 4 & $3-4$ & $4-5$ & 4 \\
\hline 2,2,2-Trichloroethyl & 4 & $4 / 5$ & 4 & $3-4$ & $4-5$ & $4-5$ \\
\hline
\end{tabular}

\section{Dyeing of wool and polyamide}

The dyeings of wool and polyamide were performed at $100^{\circ} \mathrm{C}$ and $\mathrm{pH} 7$ according to our earlier results [4] by using the chloroformates referred, and the coloured samples were submitted to the ISO $105 \mathrm{CO} 3$ test. The washfastness results are shown in Table 6 together with results previously obtained with dye 1.

\section{EXPERIMENTAL}

\section{Preparation of the mixed anhydrides 2}

Dye 1 was prepared as before [2]. To a cooled solution of the dye $(0.2 \mathrm{~g}$, $0.74 \mathrm{mmol})$ in DMF $(1 \mathrm{ml})$, triethylamine $(0.31 \mathrm{ml}, 2.27 \mathrm{mmol})$ and the chloroformate $(2.22 \mathrm{mmol})$ were added and the solution was stirred for $30 \mathrm{~min}$. The triethylamine hydrochloride was filtered off and crushed ice was added to the filtrate. A precipitate came out and, after standing for $3 \mathrm{~h}$, it was filtered and dried, and its melting point and IR were determined (Table 1). Compound 2(c) was isolated as an oil.

\section{Preparation of the amide 3 in DMF solution}

The activation was carried out as above and, then, the triethylamine hydrochloride was filtered. Cyclohexylamine $(0.085 \mathrm{ml}, 0.74 \mathrm{mmol})$ was added and the mixture kept under stirring at room temperature for $20 \mathrm{~h}$. The solvent was removed under vaccuum and the oil purified by flash chromatography (silica, petroleum ether b.p. $40-60^{\circ} \mathrm{C} /$ diethylether). Two products were isolated, the amide 3 and the esters 4 corresponding to the chloroformate used. The esters were fully characterised, while amide 3 had already been described previously [2]. 
TABLE 7

HPLC Conditions Used in the Present Study

Column

Pre-column

Filter of pre-column

Mobile phase

Flow

Equipment
Lichrospher $100 \mathrm{RP} 18,5 \mu \mathrm{m}$

Rheodyne column inlet filter $0.18 \times 6 \mathrm{~mm}$ $0.5 \times 3 \mu \mathrm{m}$

Acetonitrile/water: $90 / 10$ (by vol.)

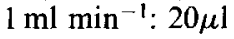

UV 410 nm, Merck Hitachi L-4250

Gilson Isocratic HPLC system

\section{Preparation of the amide 3 in aqueous medium}

The activation was carried out as above until the triethylamine hydrochloride was filtered. Cyclohexylamine $(0.085 \mathrm{ml}, 0.74 \mathrm{mmol})$ and water $(200 \mathrm{ml})$ were added to the filtrate and the mixture was refluxed for $30 \mathrm{~min}$. After cooling, the yellow solid was filtered, washed with cold water, dried and characterised by spectroscopic means.

This method was followed in three cases, as shown on Table 2, and the melting points were in agreement with published data [2] except when $p$-nitrobenzylchloroformate was used (m.p. $156.1-157.2^{\circ} \mathrm{C}$ ).

\section{HPLC conditions}

The HPLC conditions used are listed in Table 7.

\section{Dyeing of wool and polyamide}

To a cooled solution of the dye $\left(0.06 \mathrm{~g}, 2.2 \times 10^{-4} \mathrm{~mol}\right)$ in DMF $(1 \mathrm{ml})$, triethylamine $\left(0.092 \mathrm{ml}, 6.6 \times 10^{-4} \mathrm{~mol}\right)$ and the chloroformate $\left(6.6 \times 10^{-4} \mathrm{~mol}\right)$ were added and the solution was kept stirred for $30 \mathrm{~min}$. The triethylamine hydrochloride was filtered off and after adding the water $(200 \mathrm{ml})$ and the fibre $(3 \mathrm{~g})$ (the concentration of the dye in the dyebath was $2 \%$ relatively to the mass of the fibre; liquor ratio $67: 1$ ), the mixture was stirred for $30 \mathrm{~min}$ at $100^{\circ} \mathrm{C}$. The fibre was removed, washed and boiled for $15 \mathrm{~min}$ in water with Levapon TH soap ( $\left.2 \mathrm{~g} \mathrm{litre}^{-1}\right)$ and, after drying, submitted to the ISO $105 \mathrm{CO} 3$ test.

\section{CONCLUSIONS}

The results suggest that benzyl chloroformate is the best activating agent since it provides the highest fastness on wool and polyamide fibres. It does not however form the dye with the best yield in reaction with the amine 
group of cyclohexylamine, which suggests that it would not have the highest yield on wool and polyamide fibres. This analysis however depends on other factors that need to be tested in real dyeing conditions.

The results obtained with the new chloroformates are near to the ones previously obtained with ethyl chloroformate, which means that changing to these alternative activating agents does not alter the dyeing and the results fastness significantly.

\section{ACKNOWLEDGEMENTS}

We thank Junta Nacional de Investigação Cientifica e Tecnológica (Portugal) for financial support (IBQF-UM) and PRAXIS XXI for scholarships to M.S.T.G. (BD-2566-93-RM) and J.C.V.P.M. (BPD/4159/94).

\section{REFERENCES}

1. Burlington Ind. Inc., British Patent 1514 395, 1978.

2. Gomes, J. I. N. R., Griffiths, J., Maia, H. L. S., Moura, J. C. V. P. and OliveiraCampos, A. M. F., Dyes and Pigments, 1991, 17, 269.

3. Gomes, J. I. N. R., Moura, J. C. V. P., Oliveira-Campos, A. M. F., Maia, H. L. S. and Hrdina, R., European Patent 0700973 Al, 1996.

4. Gomes, J. I. N. R., Soares, G. M. B., Hrdina, R., Oliveira-Campos, A. M. F., Moura, J. C. V. P. and Maia, H. L. S. J. Soc. Dyers Colourists, 1996, $112,19$. 